\title{
Innovation, Obsolescence and Profit as Drivers of Investment in Australian Manufacturing*
}

\author{
Harry Bloch* and Maria Mangano \\ School of Economics and Finance, \\ Curtin University of Technology, \\ GPO Box U1987, \\ Perth, W.A. 6845, Australia \\ and \\ Jerry Courvisanos \\ School of Business \\ University of Ballarat, \\ P.O. Box 663, \\ Ballarat, Vic. 3353, Australia
}

* Corresponding Author,

email: h.bloch@curtin.edu.au

September 2009 ${ }^{*}$ We acknowledge financial support for this research from an Australian Research Council Discovery
Grant. 


\begin{abstract}
This paper combines Salter's analysis of capital-embodied technical change with Kalecki's analysis of financing investment from retained profits to provide a model of investment with innovation, which is applied to data from Australian manufacturing industries. In the estimated model, profit is used as a measure of the ability to invest, and the rate of technical change embodied in new equipment (i.e. process innovation) reveals the inducement to invest. These two factors combine to explain the accumulation process and its link to technical progress.
\end{abstract}

Key words: embodied technical change, Salter, Kalecki, vintage capital, investment

JEL classifications: E22, L16, 031 


\section{...technical progress cannot be regarded as automatic and independent of accumulation. Salter (1966, p. 72)}

\section{Background}

The notion that technical progress drives economic growth is well established in economics, at least since Schumpeter's (1934) theoretical analysis and Solow's (1967) empirical analysis. What is less clear is the extent to which the technical change works through investment in new capital equipment in achieving its impact on growth. In other words, are technical progress and capital accumulation independent processes or does technical progress require accumulation as suggested in the above quote from Salter (1966)?

In this paper, we develop Salter's idea that technical advance requires investment in new equipment to lead to technical progress. The strength of the inducement to invest in Salter's analysis depends on the nature of the technical advance. Technical advance that is unbiased in saving of all inputs to production only induces further investment to the extent that lower production cost enables expansion of the market through lowering product price. However, when technical advance is embodied in machines that can be used to displace labour in the production process, the inducement to invest is higher as it also includes the savings from the displacement of labour. In particular, it may be profitable to replace some existing equipment that has higher labour requirements, even though the equipment is still operational. In this context, Salter (1966, p. 54) defines obsolescence as "plants which are sufficiently outmoded to be profitably replaced." 1

There is no inevitability that firms will automatically make investment decisions to immediately order technologically superior capital stock. This is due to many factors including financial constraints, wage costs, industry competitiveness, and level of technological flexibility (or inertia). Thus, it is important to consider the Salter process within a model of investment that incorporates these other factors. The particular investment model applied in this paper is developed from Kalecki's (1968) theory of investment ordering, implying that profitability and technical change are both factors influencing the level and the variability of investment spending.

This paper develops a theoretical model that extends Kalecki's investment ordering model to incorporate Salter's analysis of obsolescence due to technical change. The theoretical model is then applied to an empirical analysis of investment spending in a cross section of Australian manufacturing industries. Differences in investment spending behaviour across industries are related to differences in profitability and the change in profitability. These are suggested by Kalecki's analysis as financial measures of the ability to invest and the inducement to invest, respectively. Measures of the rate of technical change, as suggested by Salter's analysis of obsolescence, are also included to capture the technological inducement to invest.

\footnotetext{
${ }^{1}$ Salter's analysis formalises the contribution of investment to rising productivity, which has been recognised as important in economics at least as far back as Ricardo's (1821) famous chapter, "On Machinery”. It also provides a framework for understanding the impact on investment spending of technical change, in the form of the improved technology that is embodied in new vintage capital equipment. This improved technology is the inducement for firms to invest in new equipment even when they have ample capacity. This is Salter's concept of technological obsolescence.
} 
The investment model is discussed in the following section, while the measures of technical change and other data issues are discussed in Section 3. The results from estimating regression equations for investment spending and the variability of investment spending are presented in Section 4. Conclusions are presented in the final section.

\section{Investment Model with Technical Change}

Technical change has not been easily incorporated into the theory of investment analysis. $^{2}$ The standard approach is to treat technical progress as exogenous. Even new growth theory (which attempts to add new knowledge through skill improvement) generally assumes that new knowledge is applied to existing capital equipment, obviating the need for further accumulation of capital equipment. The vintage-capital model developed by Salter (1966) distinguishes between endogenous technical progress, as measured by improvements in average productivity, and exogenous technical change, as measured by the technological innovations embodied in new equipment. Improvements in average productivity (technical progress) depend on investment in new equipment as well as on technical change, leading to the link between technical progress and accumulation identified by Salter in the opening quotation.

\subsection{Salter’s vintage-capital model with technological obsolescence}

Investment in Salter's vintage-capital model is driven by both capacity expansion and technological obsolescence. Rather than treat replacement investment as determined by physical deterioration, Salter recognises the role that embodied technical change has in making older equipment outmoded (having relatively high operating costs) and, eventually, obsolete. The condition for older equipment becoming obsolete is that the unit operating cost, in terms of variable inputs for the older equipment, exceeds the full unit cost for all inputs (including the cost of the capital equipment) using the current best-practice equipment.

Considering the three categories of labour, materials and capital input, the operating cost of the oldest vintage in use is equated with that of the newest equipment when

$\mathrm{w}_{\mathrm{t}} \lambda_{\tau-\mathrm{m}}+\mathrm{x}_{\mathrm{t}} \mu_{\tau-\mathrm{m}}=\mathrm{w}_{\mathrm{t}} \lambda_{\tau}+\mathrm{x}_{\mathrm{t}} \mu_{\tau}+\mathrm{r}_{\tau, \mathrm{t}} \kappa_{\tau}$

where $\mathrm{w}_{\mathrm{t}}$ is the wage rate at time $\mathrm{t}, \lambda_{\tau}$ is the labour required per unit of output for vintage $\tau$ capital, $x_{t}$ is the price of materials at time $t, \mu_{\tau}$ is the materials required per unit of output for vintage $\tau$ capital, $r_{\tau, t}$ is the rental price of a unit of vintage $\tau$ at time $t$ and $\kappa_{\tau}$ is the capital required per unit of output for vintage $\tau$ capital. ${ }^{3}$ The current

\footnotetext{
${ }^{2}$ For a detailed treatment of technological innovation and the difficulties of handling it as an economic concept, see Courvisanos (2005). See also Perelman (2006, p. 247) on the difficulties of modelling capital stock scrapping and its replacement by new technology.

${ }^{3}$ The rental cost of capital equipment may vary with vintage as well as with time. Different vintages may have different economic lifetimes and, hence, different rates of depreciation due to either changes in physical deterioration or, most likely, the speed of obsolescence due to technical change.
} 
vintage, $\mathrm{t}=\tau$, is assumed to be best practice and $\mathrm{m}$ is the age of replacement (assuming that all earlier vintages have higher labour cost). ${ }^{4}$

The drivers of obsolescence can be formalised by rewriting the expression in (1), incorporating $\mathrm{t}=\tau$ :

$\lambda_{\mathrm{t}-\mathrm{m}}-\lambda_{\mathrm{t}}=\left[\mathrm{r}_{\mathrm{t}, \kappa_{\mathrm{t}}}+\mathrm{x}_{\mathrm{t}}\left(\mu_{\mathrm{t}}-\mu_{\mathrm{t}-\mathrm{m}}\right)\right] / \mathrm{w}_{\mathrm{t}}$

This indicates that labour requirements of the oldest equipment in use exceed those of new equipment by an amount that rises with the capital cost of new equipment and the degree to which new equipment uses more material input, but falls with the level of the wage rate. ${ }^{5}$ Further, the difference in labour requirements on the left-hand side of (2) depends on the extent of labour-saving technical change, which for ease of exposition, is assumed to occur at a constant rate, $\Theta$, so that

$\lambda_{\mathrm{t}}=\lambda_{\mathrm{t}-\mathrm{m}} \mathrm{e}^{-\Theta \mathrm{m}}, \Theta \geq 0$

Substituting from (3) into (2) yields:

$\mathrm{e}^{-\Theta \mathrm{m}}=1-\left[\mathrm{r}_{\mathrm{t}} \kappa_{\mathrm{t}}+\mathrm{x}_{\mathrm{t}}\left(\mu_{\mathrm{t}}-\mu_{\mathrm{t}-\mathrm{m}}\right)\right] / \mathrm{w}_{\mathrm{t}} \lambda_{\mathrm{t}-\mathrm{m}}$

Taking the logarithms of both sides of (4) and rearranging terms then implies:

$m=(1 / \Theta)\left(\ln \left[1-\left[r_{t}, \kappa_{\tau}+x_{t}\left(\mu_{t}-\mu_{t-m}\right)\right] /\left(w_{t} \lambda_{t-m}\right)\right]\right)$,

This shows that $\mathrm{m}$, the length of time before capital equipment becomes obsolete, depends on requirements for inputs in both new and old equipment as well as on the current prices of the inputs.

Assuming that obsolescence occurs before physical deterioration of old capital equipment, the economic life of capital equipment, as given by $\mathrm{m}$ in (5), is inversely proportional to the rate of labour saving technical change, $\Theta$, embodied in new versus old equipment. For example, doubling the rate of labour saving technical change cuts the economic life of the equipment in half. Technical change in the use of other inputs also reduces the $\mathrm{m}$, but in a less than proportional manner. ${ }^{6}$

Depreciation is meant to cover the cost of replacing obsolete or worn out equipment. If the amount of depreciation is determined by straight-line accounting methods based on historical cost, depreciation for each machine of vintage $t-m$ is given by:

$\mathrm{d}_{\mathrm{t}-\mathrm{m}}=\mathrm{p}_{\mathrm{t}-\mathrm{m}} / \mathrm{m}$,

\footnotetext{
${ }^{4}$ Under these assumptions, all vintages between $\tau$-m and $\tau$ will have operating costs less than the full unit cost of the best-practice equipment of the current vintage. Equipment of all these intermediate vintages will continue to be fully utilised.

${ }^{5}$ The capital cost of old equipment is sunk, so it doesn't affect the expression.

${ }^{6}$ A reduction in the use of materials, $\mu_{\tau}<\mu_{\tau \text {-m }}$, through technical change has an explicit negative impact on $\mathrm{m}$ in (5), shortening the economic life of equipment by speeding up replacement. The capital requirements for older equipment do not enter explicitly into (5), as they represent a sunk cost, but technical progress in the use of capital implies a reduction in capital requirements for new equipment, that is, a lower value of $\kappa_{\tau}$ and a lower $\mathrm{m}$.
} 
where $\mathrm{p}_{\mathrm{t}-\mathrm{m}}$ is the price of machines at time $\mathrm{t}-\mathrm{m}$. This shows the amount of depreciation per machine is inversely related to the age of obsolescence. Thus, the relationship in (5) above indicates that the amount of depreciation for capital equipment is positively and proportionally related to the rate of labour saving in technical change. ${ }^{7}$ A positive, but less than proportional relationship, is expected for the rate of capital and materials saving in technical change.

Total depreciation depends on the number of machines as well as the depreciation per machine. The number of machines of each vintage in turn depends on the level of output, the capital-to-labour ratio and the distribution of output over vintages. Suppose the amount of output produced with each vintage of machines is constant at say, $\bar{x}$. Total depreciation is then given by:

$\mathrm{D}_{\mathrm{t}-\mathrm{m}}=\sum_{t-m}^{t}\left(\mathrm{p}_{\mathrm{t}-\mathrm{m}} / \mathrm{m}\right)\left(\kappa_{t-m} \bar{x}\right)$

The inverse relation between $\mathrm{m}$, the age of obsolescence, and depreciation per machine from (6) is maintained for total depreciation in (7), as are the associated implications for rates of saving of particular inputs. ${ }^{8}$ In addition, the expression in (7) suggests total depreciation is affected by the rate of capital saving in technical change. In particular, when technical change is capital using, $\kappa_{t-m}$ is rising over time and so is depreciation.

Gross investment consists of depreciation and net investment. Technical change that leads to a rise in depreciation through a shorter life for capital equipment (faster obsolescence) thus raises gross investment. In addition, any cost-reducing technical change can have an increasing effect on gross investment by leading to positive net investment as firms expand production capacity.

In summary, gross investment is expected to increase with the rate of technical change embodied in capital equipment. The main mechanism identified is the shortening of the working life of capital equipment, although there can be additional impact through cost reduction leading to net investment to expand production capacity. The rate of labour-saving is identified as having a particularly strong impact, as the age of obsolescence is found to be inversely proportional. Material saving and capital saving also tend to shorten the working life of capital equipment and encourage net investment. However, in the case of capital saving this positive impact of capital saving on investment may be offset to some extent by the decline in capital-to-output ratio associated with newer vintages of machines. ${ }^{9}$

\footnotetext{
${ }^{7}$ In this formulation, the reciprocal of the age of obsolescence corresponds to Kalecki's (1968) concept of the "pay off period", the period over which the capital invested is recovered. In terms of accounting concepts, d may be thought of as an allowance for amortisation of the declining economic value of old equipment (due to its low productivity relative to new equipment) rather than depreciation as an allowance for physical deterioration.

${ }^{8}$ The age of obsolescence affects the number of vintages over which the sum is taken in (7), but this is offset by a change in the output per vintage if the total output level is unchanged.

${ }^{9}$ In practice, technical change is found to be generally capital using, which raises gross investment through the effect on the capital-to-labour ratio but lowers gross investment through its impact on raising the age of obsolescence (a higher capital-to-output ratio makes new machines more expensive and postpones their acquisition).
} 


\subsection{Kalecki's model of investment adapted for technical change}

Kalecki (1971, p. viii) notes in his writings, “...[that] there is a continuous search for new solutions in the theory of investment decisions, where even the last paper represents - for better or for worse - a novel approach.” In this last paper Kalecki (1968), which is reprinted with minor changes as Kalecki (1971, Chapter 15), integrates the treatment of technical progress into his approach of moving equilibrium in order to analyse long-run growth together with the business cycle. The analysis below emphasises this approach. ${ }^{10}$

In Kalecki (1968) technical change is linked to investment decisions through the gain in profits captured by new plants. Kalecki equates this gain to the saving in labour cost from taking old equipment out of production. Using (2) above, this saving per unit of output is equal to the capital cost of new equipment minus the saving in material cost between old and new equipment:

$\mathrm{w}_{\mathrm{t}} \lambda_{\mathrm{t}-\mathrm{m}}-\mathrm{w}_{\mathrm{t}} \lambda_{\mathrm{t}}=\mathrm{r}_{\mathrm{t}} \kappa_{\mathrm{t}}-\left(\mathrm{x}_{\mathrm{t}} \mu_{\mathrm{t}-\mathrm{m}}-\mathrm{x}_{\mathrm{t}} \mu_{\mathrm{t}}\right)$

Cost savings in materials have been generally small relative to cost savings in labour (see reported estimates in Section 3 below) and, to simplify, are ignored from here on.

If differences in material cost are ignored, then the saving of labour cost from (8) for the amount of output shifted from old to new equipment is equal to the capital cost of the new equipment. This capital cost consists of a depreciation charge and a return to capital. When scrapping of equipment is determined by technological obsolescence, the depreciation charge for old equipment is given by (6). However, this is the same as the depreciation charge for new equipment as long as technical change occurs at a constant rate and the price of capital equipment is constant. Thus, the factors that are identified as affecting the depreciation charge in (6) are, in turn, drivers of investment decisions in Kalecki's model, as long as a constant rate of technical change and constant capital price are assumed.

Laramie and Mair (2003) identify two sources of technological obsolescence that emerge from the Kalecki (1968) investment model. One is the rising cost of operating the capital stock due to the ageing process. Even with no innovation occurring, new replacement investment would be relatively more productive than the existing capital stock. This would result in a rising increment of profits from the new investment compared to the old capital stock. Kalecki's technical change coefficient would be positive even if all the replacement investment had no embodied technical improvements. However, Kalecki considered this aspect of technological obsolescence as minor since most replacement investment has embodied in it at least some element of technical change.

The other source is directly related to technical change, and is the source emphasised by Kalecki (1968). In this case, obsolescence of the existing capital occurs even if the

\footnotetext{
${ }^{10}$ In the earlier treatments, such as given in Kalecki (1971, Chapter 10 based on Kalecki (1954), depreciation is noted as being due to wear and tear or obsolescence. However, there is no discussion of obsolescence as due to technical change.
} 
productivity of the existing capital stock remains constant. Obsolescence occurs here because the new technically superior investment reduces the relative productivity of the existing capital stock. ${ }^{11}$ Thus, the new investment is not merely replacing ageing capital stock, but adding a new element to the capital stock. Depending on the nature of the innovation introduced, the power of the technical change coefficient in this case is stronger than that of the first (no innovation) case. The power of this coefficient would be based on the productivity and value creation gains that emerge directly from embodied technical improvements. ${ }^{12}$

The Kalecki investment orders function, with its technical change coefficient, is appealing in a theoretical form. However, no data are collected on increments of profit associated with new investment - either replacement or innovation investment. There is a need for an alternative approach to specifying the investment function that is faithful to Kalecki's theory but that allows data to be applied.

A Kaleckian empirical study linking innovation and investment by Courvisanos (2007) relates Australian private new capital expenditure (investment) to profits and research and development (R\&D) expenditure. In the total sample, both lagged profits and lagged R\&D influence investment with nearly equal significance. Panel data analysis shows that in mature industries profits are much more influential, while growth industries show marked diversity, with some reflecting high R\&D impact and others very low. One difficulty with this approach is that technical change in Australia generally entails the use of overseas technology and its application to Australian conditions. Much of this technology is embodied in imported capital equipment and need not be reflected in R\&D expenditures of domestic firms.

Two issues arising from the Courvisanos (2007) study that provide a basis for investigation using the Salter approach are (i) the diverse nature of embodied technical change stemming out of more than just R\&D, and (ii) labour costs and their influence on this technical change. The Salter approach allows the investigation directly of investment with process innovation, without needing to trace back to sources of technological obsolescence. This provides a direct method of understanding the impact of technical change (inducement to invest) and profits (ability to invest) in the investment ordering process.

\subsection{Investment ordering when innovation is embodied in capital equipment}

Laramie et al. (2007) derive strong econometric results when using U.K. data on manufacturing and construction to estimate an investment orders function that incorporates Kalecki's (1968) function with Keynes’s susceptibility for long-term expectations to change. The susceptibility model of investment specified is

$\mathrm{I}_{\mathrm{t}}=f\left(\mathrm{P}_{\mathrm{t}-1}, \Delta \mathrm{P}, g_{\mathrm{t}-1}, c_{\mathrm{t}-1}\right)$

\footnotetext{
${ }^{11}$ Laramie and Mair (2003) illustrate this situation with the example of a new energy-efficient light bulb producing more light relative to wattage power, compared to the standard light bulb which is still in actual terms just as efficient as prior to the introduction of the new light bulb.

${ }^{12}$ Perelman (2006) criticises Keynesian economists (of all descriptions) for ignoring the productivity power of replacement investment, despite it being almost two-and-half times as large as net additions to the capital stock.
} 
where $I_{t}$ is aggregate investment orders in the current period $t ; P_{t-1}$, is previous period $(\mathrm{t}-1)$ level of profits; $\Delta \mathrm{P}$ is actual increment in profit levels from $(\mathrm{t}-2)$ to $(\mathrm{t}-1) ; g_{\mathrm{t}-1}$ is previous period gearing ratio; and $c_{\mathrm{t}-1}$ is previous period capacity utilisation. ${ }^{13}$ Consistent with Kalecki, this function identifies the investment order decisions with gestation lags to when these orders are expended and in full operation. National statistics quote investment expenditure data that identifies the realisation of the investment orders, including any modifications to the orders that may have occurred during the gestation period.

Laramie et al. (2007, p. 197) find that previous profits, lagged by one and two quarters as a set, have the greatest impact on new investment orders. They state that "... [b]oth of these profit coefficients are positive, indicating that it is unlikely that $\Delta \mathrm{P}$ plays a part in influencing new orders”. Capacity utilisation also plays a significantly large role, while gearing as a financial constraint has only a small impact on their results. Although capacity utilisation is important in the Laramie et al. results, its specification in that study is only as a proxy, where $c_{\mathrm{t}-1}$ is the difference between current output $(\mathrm{Y})$ and output associated with target capacity utilisation (which is a fixed proportion of capital stock). In their results they identify that when Y falls below approximately two-thirteenths of the existing capital stock, then capacity utilisation has a negative influence on new orders. ${ }^{14}$

From a theoretical perspective, technical change should be incorporated into investment theory because innovation alters the inducement to invest by changing the cost of production or altering product demand. Kalecki (1968) and Laramie et al. (2007) both imply technical progress in their investment function specifications but only indirectly; the former by theory and the latter by empirical estimation. Salter (1966) links the inducement to invest to technical change by utilising a vintage capital model in which innovation is embodied in capital equipment.

Specifically, Salter (1966, pp. 74-5) determines that the "margin of obsolescence" appears in a particular industry where the unit total cost of production using bestpractice capital stock equals the unit operating cost of the oldest vintage plant. Labour hiring and materials are the operating costs in this calculation. On this margin, a particular capital stock in a particular industry will be such that technological obsolescence and technical change are mirror images. This can be linked to the above Kaleckian investment function through capacity utilisation on the basis that the "margin of obsolescence" can be alternatively identified as where the total cost of new capacity equals the operating costs of outmoded existing capacity. Thus, when the former becomes less than the latter, then existing marginal capacity becomes technologically obsolete. If labour and other input costs rise, such that operating existing capital becomes costlier than introducing new capital stock, then the existing capital stock will be replaced with new labour saving best-practice capital stock.

Salter goes on to identify mature industries where excess capacity is so high that there is no technological obsolescence since the cost of replacement of existing plant is not

\footnotetext{
${ }^{13}$ For details, see Courvisanos (1996, pp. 114-62).

${ }^{14}$ Indirectly, this study ascertains technological obsolescence when it estimates the average optimal life of U.K. capital stock (the inverse of capital-output ratio) as approximately 6.57 years.
} 
profitable. ${ }^{15}$ In such industries, given existing new knowledge, technical change will not happen until labour costs increase sufficiently to make investment in new capital stock profitable. In new growth innovation-bound industries there is no existing capital stock, so there is no issue of existing operating costs and no excess capacity. Such a characterisation of investment with process innovation brings the analysis directly back to the Kalecki (1968) investment orders formulation that began this section, with profits and profit increments as the investment variables. What Salter brings to the analysis is a clear decision-based convention or rule governing when new embodied technical change should be introduced into the investment ordering process, subject to demand growth. In fact, it is new best-practice capital stock that can be used most effectively to meet any projected demand growth.

\section{Technological Change and Obsolescence in Australian Manufacturing}

Bloch (2009) fits a system of equations including a cost function and derived input demand functions to time-series data for the period 1968 to 2000 for each of 38 Australian manufacturing industries. The cost function is in the linear form of the right-hand side of (1), namely

$\mathrm{C}_{\mathrm{t}}=\mathrm{w}_{\mathrm{t}} \lambda_{\tau}+\mathrm{x}_{\mathrm{t}} \mu_{\tau}+\mathrm{r}_{\mathrm{t}} \kappa_{\tau}$

where $c_{t}$ is the unit cost of production using new vintage (best-practice) equipment. Cost data for new vintage equipment are not directly observed. Rather, it is assumed that product price is related to unit cost through a markup. Unit cost is replaced by price in (10), while the right-hand side is multiplied by one plus the markup. ${ }^{16}$

The amount required of each input per unit of output; $\lambda_{\tau}$, for labour, $\mu_{\tau}$ for materials and $\kappa_{\tau}$ for capital; is assumed to change at a constant rate over time, as in (3) above for labour input. The input demand equation for labour replaces the unit labour requirements for vintage $t$ capital with the actual ratio of labour input to output in that period, and relates this to an exponential time trend with the coefficient of time providing an estimate of the rate of labour-saving technical change (RLS). A similar relationship is used for materials demand, yielding an estimate of the rate of materials saving (RMS). No separate equation is used for capital input, with the estimate of the rate of capital saving (RKS) coming instead directly from the cost function (where the amount required of each input is assumed to follow the same exponential time path as in the input demand equations for labour and materials). ${ }^{17}$

\footnotetext{
${ }^{15}$ Industry maturity is of course at least partly a reflection of the lack of technical change, at least in a model of capital-embodied technical change. If technical change is substantial and embodied in capital, the total cost of production using new equipment falls below the operating cost of older equipment and, in this sense, excess capacity is removed.

${ }^{16}$ Kalecki (1971) allows for imperfect competition by introducing a markup of price over unit prime cost. The markup used in Bloch (2007) multiplies full unit cost. This is appropriate given the variety of vintages in use with disparate unit prime cost. Salter (1966) relates price to full unit cost, but assumes competitive equilibrium with price equal to cost, that is the markup equals zero. Thus, Bloch (2007) combines Salter's analysis of the influence of costs with Kalecki's markup pricing analysis. See Bloch (1990) for a discussion of applying Kalecki's pricing analysis to situations in which there are cost differences across firms in an industry.

${ }^{17}$ Omitting a separate equation for capital input avoids the conceptual problem of measuring the quantity of capital over time when relative input prices are changing (see Harcourt, 1972) and the practical problem of needing to incorporate an unknown age of obsolescence into the estimation.
} 
The estimates of the rates of technical change for each input along with their respective t-ratio are shown in Table 1 . Also shown in Table 1 is a calculated overall rate of cost diminution (RCD), which measures the effect of technical change on unit production cost by taking a weighted average of the rates of input saving. The weights used in this average are the share of each input in industry revenues. ${ }^{18}$

A positive coefficient for a rate of input saving in Table 1 indicates that technical change in the industry is associated with saving that input in the production process, while a negative coefficient indicates that technical change is associated with more intensive use of the input. An outstanding feature of the table is that there is evidence of labour saving in each industry, as all coefficients are positive and statistically significant at the 5 per cent level or better. The estimated rates of labour saving range from .007 in Bakery Products, to .051 in Sheet Metal Products. Further, in every industry the rate of labour saving is greater than the rate of capital saving, and in only one industry, Log Sawmilling, it is greater than the rate of materials saving, indicating a labour saving bias to technical change in Australian manufacturing. Based on the model employed, this reveals that overall manufacturing firms in Australia tend to save on labour costs by abandoning older vintage equipment as technologically obsolete in favour of technical change embodied in new equipment.

Rates of materials saving shown in Table 1 are mostly positive but small and often not statistically significant. In contrast, the coefficients for the rates of capital saving are mostly negative, suggesting that technical change is mostly capital using (negative coefficients) but not necessarily statistically significant. Finally, the rate of cost diminution is generally positive, indicating that technical change has reduced production costs in most Australian manufacturing industries over the sample period. $^{19}$

\footnotetext{
${ }^{18}$ Shares of industry cost are the appropriate weights for a rate of cost diminution due to technical change, but no data on industry costs are readily available. The share of capital input is calculated as a residual and therefore includes any economic profit or loss, which might lead to measurement error for the rate of cost diminution.

${ }^{19}$ Technical change also contributes indirectly to cost reduction due to the bias towards labour saving. Wage rates have risen much faster than the price of materials or the rental price of capital, so technical change has led to economising on the relative expensive input to production. The resulting cost savings is akin to substituting materials and, especially, capital for the increasingly relatively expensive labour. However, there is no presumption that the production process permits changes to input proportions, except indirectly through the acquisition of new machines with embodied technology. See Bloch and Madden (1995) for an earlier application of this approach to Australian manufacturing.
} 
Table 1 - Rates of Technical Change and Cost Diminution for Australian Manufacturing (coefficients in bold, and t-ratios in parentheses)

\begin{tabular}{|c|c|c|c|c|c|c|c|c|c|}
\hline Industry & RCD & RKS & RLS & RMS & Industry & RCD & RKS & RLS & RMS \\
\hline Fruit and Vegetable Processing (213) & 0.01762 & $\begin{array}{r}-\mathbf{0 . 0 3 4 8 3 4} \\
-(9.258) \\
\end{array}$ & $\begin{array}{r}\mathbf{0 . 0 3 3 6 0 6} \\
(43.090)\end{array}$ & $\begin{array}{r}\mathbf{0 . 0 1 1 7 0 0} \\
(8.417)\end{array}$ & Petroleum and Coal Product mfg (252) & $\begin{array}{c}- \\
0.01512\end{array}$ & $\begin{array}{r}-\mathbf{0 . 0 6 7 7 6 0} \\
-(1.443)\end{array}$ & $\begin{array}{r}\mathbf{0 . 0 3 4 2 4 1} \\
(10.904)\end{array}$ & $\begin{array}{r}-\mathbf{0 . 0 4 0 2 0 6} \\
-(5.146)\end{array}$ \\
\hline Oil and Fat mfg (214) & 0.03318 & $\begin{array}{r}-\mathbf{0 . 1 9 6 7 2 7} \\
-(3.083) \\
\end{array}$ & $\begin{array}{r}\mathbf{0 . 0 2 4 8 6 3} \\
(7.740)\end{array}$ & $\begin{array}{r}\mathbf{0 . 0 1 3 8 8 5} \\
(4.354)\end{array}$ & Basic Chemical mfg (253) & 0.01039 & $\begin{array}{r}-\mathbf{0 . 0 0 4 4 3 8} \\
-(1.143)\end{array}$ & $\begin{array}{r}\mathbf{0 . 0 4 1 9 9 0} \\
(39.248)\end{array}$ & $\begin{array}{r}\mathbf{0 . 0 1 4 0 1 3} \\
(7.941)\end{array}$ \\
\hline Flour Mill and Cereal Food mfg (215) & 0.00983 & $\begin{array}{r}-\mathbf{0 . 0 8 0 7 6 5} \\
-(10.428)\end{array}$ & $\begin{array}{r}\mathbf{0 . 0 2 5 4 8 9} \\
(23.045)\end{array}$ & $\begin{array}{r}\mathbf{0 . 0 1 5 8 4 6} \\
(9.042)\end{array}$ & Other Chemical Product mfg (254) & 0.00351 & $\begin{array}{r}-\mathbf{0 . 0 2 3 2 1 1} \\
-(7.782)\end{array}$ & $\begin{array}{r}\mathbf{0 . 0 4 4 1 4 1} \\
(53.868)\end{array}$ & $\begin{array}{r}\mathbf{0 . 0 0 5 0 9 1} \\
(3.609)\end{array}$ \\
\hline Bakery Product mfg (216) & 0.05161 & $\begin{array}{r}-\mathbf{0 . 1 5 5 6 7 4} \\
-(4.584)\end{array}$ & $\begin{array}{r}\mathbf{0 . 0 0 7 2 5 7} \\
(8.286)\end{array}$ & $\begin{array}{r}-\mathbf{0 . 0 0 1 1 1 5} \\
-(0.549)\end{array}$ & Rubber Product mfg (255) & 0.00910 & $\begin{array}{r}-\mathbf{0 . 0 0 5 4 4 7} \\
-(1.304)\end{array}$ & $\begin{array}{r}\mathbf{0 . 0 3 1 5 8 7} \\
(22.726)\end{array}$ & $\begin{array}{r}\mathbf{0 . 0 0 6 4 9 0} \\
(3.053)\end{array}$ \\
\hline Other Food mfg (217) & 0.00300 & $\begin{array}{r}-\mathbf{0 . 0 2 3 8 9 6} \\
-(5.982) \\
\end{array}$ & $\begin{array}{r}\mathbf{0 . 0 1 8 1 8 4} \\
(15.928) \\
\end{array}$ & $\begin{array}{r}\mathbf{0 . 0 0 7 8 0 5} \\
(3.073) \\
\end{array}$ & Plastic Product mfg (256) & $\begin{array}{c}- \\
0.00104\end{array}$ & $\begin{array}{r}-\mathbf{0 . 0 4 0 1 6 5} \\
-(8.168)\end{array}$ & $\begin{array}{r}\mathbf{0 . 0 1 9 4 0 9} \\
(9.664)\end{array}$ & $\begin{array}{r}\mathbf{0 . 0 0 3 1 1 1} \\
(1.963)\end{array}$ \\
\hline Beverage and Malt mfg (218) & 0.00080 & $\begin{array}{r}-\mathbf{0 . 0 4 6 7 5 6} \\
-(11.560)\end{array}$ & $\begin{array}{r}\mathbf{0 . 0 4 0 8 0 4} \\
(45.910)\end{array}$ & $\begin{array}{r}\mathbf{0 . 0 1 0 8 2 3} \\
(6.555)\end{array}$ & Glass and Glass Product mfg (261) & 0.01983 & $\begin{array}{r}\mathbf{0 . 0 1 9 0 2 5} \\
(5.093)\end{array}$ & $\begin{array}{r}\mathbf{0 . 0 5 0 6 5 6} \\
(28.709)\end{array}$ & $\begin{array}{r}\mathbf{0 . 0 0 1 0 4 2} \\
(0.234)\end{array}$ \\
\hline Tobacco Product mfg (219) & 0.01126 & $\begin{array}{r}\mathbf{- 0 . 0 5 1 1 8 4} \\
-(6.932) \\
\end{array}$ & $\begin{array}{r}\mathbf{0 . 0 3 0 4 4 0} \\
(6.549) \\
\end{array}$ & $\begin{array}{r}\mathbf{0 . 0 0 6 2 3 7} \\
(1.950) \\
\end{array}$ & Ceramic mfg (262) & $\begin{array}{c}- \\
0.00400\end{array}$ & $\begin{array}{r}-\mathbf{0 . 0 1 3 0 4 0} \\
-(2.107) \\
\end{array}$ & $\begin{array}{r}\mathbf{0 . 0 2 4 5 1 2} \\
(17.714) \\
\end{array}$ & $\begin{array}{r}-\mathbf{0 . 0 1 4 3 0 6} \\
-(3.256) \\
\end{array}$ \\
\hline Textile Fibre, Yarn and Woven Fabric mfg (221) & 0.02523 & $\begin{array}{r}-\mathbf{0 . 0 0 1 7 9 7} \\
-(0.335)\end{array}$ & $\begin{array}{r}\mathbf{0 . 0 4 9 5 5 5} \\
(67.830)\end{array}$ & $\begin{array}{r}\mathbf{0 . 0 2 9 5 6 8} \\
(13.546)\end{array}$ & Cement, Lime, Plaster and Concrete Product mfg (263) & $\begin{array}{c}- \\
0.00278\end{array}$ & $\begin{array}{r}-\mathbf{0 . 0 0 3 3 8 4} \\
-(0.643)\end{array}$ & $\begin{array}{r}\mathbf{0 . 0 2 1 2 2 6} \\
(24.831)\end{array}$ & $\begin{array}{r}-\mathbf{0 . 0 0 8 3 9 9} \\
-(2.643)\end{array}$ \\
\hline Textile Product mfg (222) & 0.00838 & $\begin{array}{r}-\mathbf{0 . 0 1 0 5 3 6} \\
-(1.188) \\
\end{array}$ & $\begin{array}{r}\mathbf{0 . 0 1 9 0 3 5} \\
(8.754) \\
\end{array}$ & $\begin{array}{r}\mathbf{0 . 0 0 7 4 5 0} \\
(3.689) \\
\end{array}$ & Non-metallic Mineral Product mfg (264) & 0.05429 & $\begin{array}{r}-\mathbf{0 . 0 7 6 3 1 9} \\
-(6.568) \\
\end{array}$ & $\begin{array}{r}\mathbf{0 . 0 2 7 0 4 3} \\
(12.905) \\
\end{array}$ & $\begin{array}{r}\mathbf{0 . 0 0 6 0 7 0} \\
(1.053) \\
\end{array}$ \\
\hline Knitting Mills (223) & 0.02354 & $\begin{array}{r}\mathbf{0 . 0 3 4 6 6 9} \\
(4.170)\end{array}$ & $\begin{array}{r}\mathbf{0 . 0 3 8 7 2 2} \\
(11.123)\end{array}$ & $\begin{array}{r}-\mathbf{0 . 0 0 1 1 8 6} \\
-(0.146)\end{array}$ & Iron and Steel mfg (271) & 0.01111 & $\begin{array}{r}-\mathbf{0 . 0 1 7 5 2 7} \\
-(3.136)\end{array}$ & $\begin{array}{r}\mathbf{0 . 0 4 5 3 0 6} \\
(20.873)\end{array}$ & $\begin{array}{r}\mathbf{0 . 0 1 1 2 4 8} \\
(4.207)\end{array}$ \\
\hline Clothing mfg (224) & 0.01539 & $\begin{array}{r}\mathbf{- 0 . 0 1 8 7 8 4} \\
-(4.082) \\
\end{array}$ & $\begin{array}{r}\mathbf{0 . 0 3 3 1 8 4} \\
(34.387) \\
\end{array}$ & $\begin{array}{r}\mathbf{0 . 0 2 1 7 7 9} \\
(8.597) \\
\end{array}$ & Basic Non-ferrous Metal mfg (272) & $\begin{array}{c}- \\
0.00366\end{array}$ & $\begin{array}{r}-\mathbf{0 . 0 9 2 5 8 2} \\
-(8.083) \\
\end{array}$ & $\begin{array}{r}\mathbf{0 . 0 2 8 6 8 7} \\
(13.213) \\
\end{array}$ & $\begin{array}{r}\mathbf{0 . 0 2 1 7 8 5} \\
(5.359) \\
\end{array}$ \\
\hline Footwear mfg (225) & 0.01001 & $\begin{array}{r}\mathbf{0 . 0 0 1 1 1 6} \\
(0.178)\end{array}$ & $\begin{array}{r}\mathbf{0 . 0 2 2 3 9 8} \\
(21.809)\end{array}$ & $\begin{array}{r}\mathbf{0 . 0 0 5 8 4 8} \\
(2.033)\end{array}$ & Non-ferrous Basic Metal Product mfg (273) & $\begin{array}{c}- \\
0.01067\end{array}$ & $\begin{array}{r}-\mathbf{0 . 4 1 3 2 0 1} \\
-(1.454)\end{array}$ & $\begin{array}{r}\mathbf{0 . 0 3 1 8 9 2} \\
(17.422)\end{array}$ & $\begin{array}{r}\mathbf{0 . 0 1 5 7 5 6} \\
(4.925)\end{array}$ \\
\hline Leather and Leather Product mfg (226) & 0.01001 & $\begin{array}{r}\mathbf{0 . 0 0 0 8 6 8} \\
(0.048) \\
\end{array}$ & $\begin{array}{r}\mathbf{0 . 0 3 6 5 1 3} \\
(10.553) \\
\end{array}$ & $\begin{array}{r}-\mathbf{0 . 0 2 5 7 2 1} \\
-(8.019) \\
\end{array}$ & Structural Metal Product (274) & 0.00605 & $\begin{array}{r}-\mathbf{0 . 0 0 1 3 9 3} \\
-(0.181) \\
\end{array}$ & $\begin{array}{r}\mathbf{0 . 0 1 4 1 9 8} \\
(12.052) \\
\end{array}$ & $\begin{array}{r}\mathbf{0 . 0 0 4 6 4 8} \\
(2.321) \\
\end{array}$ \\
\hline Log Sawmilling and Timber Dressing (231) & 0.02547 & $\begin{array}{r}-\mathbf{0 . 1 1 9 6 1 2} \\
-(5.144) \\
\end{array}$ & $\begin{array}{r}\mathbf{0 . 0 1 4 1 4 1} \\
(11.313) \\
\end{array}$ & $\begin{array}{r}\mathbf{0 . 0 1 7 4 9 0} \\
(3.039) \\
\end{array}$ & Sheet Metal Product (275) & 0.01386 & $\begin{array}{r}\mathbf{0 . 0 1 1 0 2 5} \\
(1.985) \\
\end{array}$ & $\begin{array}{r}\mathbf{0 . 0 5 1 6 3 2} \\
(19.927) \\
\end{array}$ & $\begin{array}{r}-\mathbf{0 . 0 1 4 1 4 9} \\
-(2.815) \\
\end{array}$ \\
\hline Other Wood Product mfg (232) & 0.02008 & $\begin{array}{r}-\mathbf{0 . 0 5 6 3 6 5} \\
-(3.695) \\
\end{array}$ & $\begin{array}{r}\mathbf{0 . 0 1 5 0 0 8} \\
(14.461)\end{array}$ & $\begin{array}{r}\mathbf{0 . 0 1 1 9 3 8} \\
(3.672) \\
\end{array}$ & Fabricated Metal Product mfg (276) & 0.01428 & $\begin{array}{r}-\mathbf{0 . 0 4 5 0 2 1} \\
-(7.063) \\
\end{array}$ & $\begin{array}{r}\mathbf{0 . 0 0 9 3 2 5} \\
(13.080) \\
\end{array}$ & $\begin{array}{r}\mathbf{0 . 0 1 2 8 0 4} \\
(4.620) \\
\end{array}$ \\
\hline Paper and Paper Product mfg (233) & 0.00410 & $\begin{array}{r}-\mathbf{- 0 . 0 2 2 8 6 3} \\
-(7.666) \\
\end{array}$ & $\begin{array}{r}\mathbf{0 . 0 4 1 6 1 8} \\
(49.407) \\
\end{array}$ & $\begin{array}{r}\mathbf{0 . 0 0 7 3 3 3} \\
(4.791) \\
\end{array}$ & Motor Vehicle and Part mfg (281) & $\begin{array}{c}- \\
0.00263 \\
\end{array}$ & $\begin{array}{r}-\mathbf{0 . 0 3 3 9 9 1} \\
-(4.866) \\
\end{array}$ & $\begin{array}{r}\mathbf{0 . 0 2 2 3 4 1} \\
(18.096) \\
\end{array}$ & $\begin{array}{r}\mathbf{0 . 0 0 2 1 4 4} \\
(1.181) \\
\end{array}$ \\
\hline Printing and Services to Printing (241) & 0.02731 & $\begin{array}{r}-\mathbf{0 . 0 5 9 0 4 0} \\
-(7.231)\end{array}$ & $\begin{array}{r}\mathbf{0 . 0 2 9 8 8 0} \\
(30.584)\end{array}$ & $\begin{array}{r}\mathbf{0 . 0 1 8 1 6 1} \\
(5.365)\end{array}$ & Other Transport Equipment mfg (282) & 0.00374 & $\begin{array}{r}\mathbf{0 . 0 0 6 5 3 6} \\
(0.339)\end{array}$ & $\begin{array}{r}\mathbf{0 . 0 3 2 2 1 5} \\
(13.693)\end{array}$ & $\begin{array}{r}-\mathbf{0 . 0 2 1 1 5 5} \\
-(6.601)\end{array}$ \\
\hline Publishing (242) & 0.01445 & $\begin{array}{r}-\mathbf{0 . 0 6 5 0 4 1} \\
-(7.067) \\
\end{array}$ & $\begin{array}{r}\mathbf{0 . 0 1 6 8 4 9} \\
(11.736) \\
\end{array}$ & $\begin{array}{r}\mathbf{0 . 0 2 0 1 8 1} \\
(4.941) \\
\end{array}$ & Industrial Machinery and Equipment mfg (286) & 0.00260 & $\begin{array}{r}-\mathbf{0 . 0 1 6 9 9 7} \\
-(3.421) \\
\end{array}$ & $\begin{array}{r}\mathbf{0 . 0 1 9 4 8 5} \\
(16.971) \\
\end{array}$ & $\begin{array}{r}-\mathbf{0 . 0 0 0 9 1 4} \\
-(0.579) \\
\end{array}$ \\
\hline Petroleum Refining (251) & 0.00616 & $\begin{array}{r}\mathbf{0 . 0 1 8 3 7 7} \\
(1.559)\end{array}$ & $\begin{array}{r}\mathbf{0 . 0 3 9 9 7 8} \\
(5.950)\end{array}$ & $\begin{array}{r}-\mathbf{0 . 0 5 5 0 6 9} \\
-(9.145)\end{array}$ & Furniture mfg (292) & $\begin{array}{c}- \\
0.00234\end{array}$ & $\begin{array}{r}-\mathbf{0 . 0 0 1 9 7 5} \\
-(0.391)\end{array}$ & $\begin{array}{r}\mathbf{0 . 0 0 8 4 1 0} \\
(7.836)\end{array}$ & $\begin{array}{r}-\mathbf{0 . 0 0 7 8 6 4} \\
-(4.703)\end{array}$ \\
\hline
\end{tabular}




\section{Investment and Technical Change: Results for Australian Manufacturing}

The manufacturing sector data in Table 1 are for 3-digit ANZSIC categories identified as 38 separate industry groupings. ${ }^{20}$ There are no available investment data for two industries (viz. 218 Beverage and Malt, 219 Tobacco Product), leaving 36 industries with investment data corresponding to the estimates of input saving rates and cost diminution. Each of the three input-saving rate estimates and the rate of cost diminution are applied to the four-year average Australian investment manufacturing data for each industry group over the financial (July-June) years 2001-02 to 2004-05. These four years are a complete trough-to-peak expansion in the Australian manufacturing investment cycle (see Figure 1), following a decline of manufacturing investment until mid-2001 as a result of a minor recession in the Australian economy in 1999-2001. ${ }^{21}$ This enables an examination of the investment ordering process at the time when there is relatively low susceptibility to over-investment and when firms would be keen to introduce new, efficient capital stock to meet rising aggregate demand in the economy.

The investment data for each industry group are divided by the average industry value added (IVA) over the same four-year period to create an "investment rate" variable that is comparable across industries of radically different size. Regressions are used to investigate the significance that various profit variables and Salter-based technical change variables (RLS, RKS, RMS and RCD) have on the investment rate so identified. Each regression investigates one of the technical change rates with two profit rate variables: (i) the average profits in each industry as a ratio of average IVA for the same four-year period, and (ii) the change in profits as a ratio of average IVA for the four years. The average profit rate is a measure of the ability to invest, while the change in profits is a measure of the inducement to invest in terms of the Kaleckian investment model described in the previous section.

Figure 1 - Manufacturing Investment March 2001 to March 2006

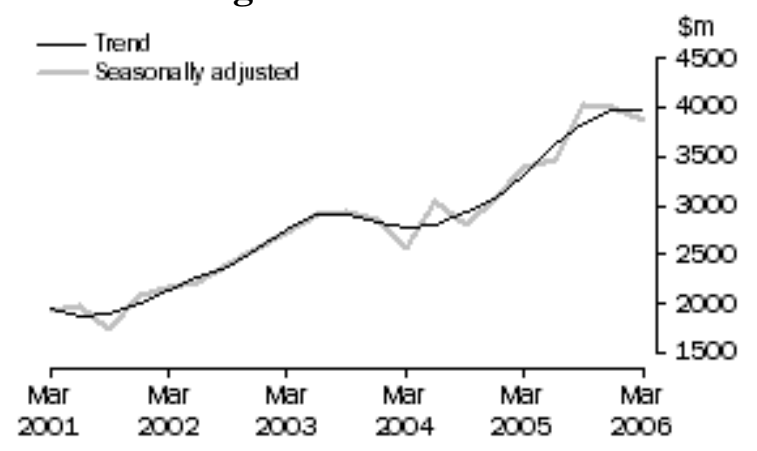

Source: Private New Capital Expenditure and Expected Expenditure, Australia, March 2006, Australian Bureau of Statistics (ABS), Catalogue No. 5625.0

\footnotetext{
${ }^{20}$ The datum available for this study at the lowest level of specificity is the 3-digit industry level. There is no datum of this kind available at firm level.

${ }^{21}$ This expansion ended as at December 2005, as reported in the September 2006 release of the capital expenditure for manufacturing data in the following terms: "The trend estimate for Manufacturing has decreased $4.3 \%$ this [September] quarter, the third consecutive fall [since the peak in December 2005]. In seasonally adjusted terms, the estimate has decreased $2.5 \%$ which is the fourth consecutive fall.”
} 
The results from the regressions relating the various rates of technical change and profit measures to investment rates in Australian manufacturing are presented in Table 2. These results show that, among the technical change variables, only labour saving has a statistically significant coefficient. It is positive and indicates that each rise of .01 in the rate of labour saving is associated with a 0.0126 rise in the investment rate.

The positive and significant coefficient of the labour saving variable, combined with the absence of significance for any of the other technical change variables supports Salter's model of technical change being capital embodied and having a labour saving bias. As explained in the analysis in Section 2.1, depreciation and, hence, gross investment is increased through faster technological obsolescence. That analysis points to a proportional relationship between the rate of labour saving in technical change and the amount of depreciation; but a less than proportional relationship for the rates of saving in other inputs. Cost diminution, as a weighted average of the rates of input saving, is expected to have an intermediate effect.

Table 2 - Average Investment Rate in Australian Manufacturing 2001/02 to 2004/05 - Regression Results

\begin{tabular}{|c|c|c|c|c|}
\hline & \multicolumn{4}{|c|}{ Estimated coefficient } \\
\hline & RCD & RLS & RKS & RMS \\
\hline Intercept & $\begin{array}{l}0.0709 \\
(0.025)\end{array}$ & $\begin{array}{l}0.0289 \\
(0.0317)\end{array}$ & $\begin{array}{l}0.0683 \\
(0.0252)\end{array}$ & $\begin{array}{l}0.0679 \\
(0.0254)\end{array}$ \\
\hline Avg Operating Profit/Avg IVA & $\begin{array}{l}0.1359 \\
(0.099)\end{array}$ & $\begin{array}{l}0.16276^{*} \\
(0.0947)\end{array}$ & $\begin{array}{l}0.1453 \\
(0.1003)\end{array}$ & $\begin{array}{l}0.1444 \\
(0.0993)\end{array}$ \\
\hline Change in Operating Profit/Avg IVA & $\begin{array}{l}0.08034 \\
(0.049)\end{array}$ & $\begin{array}{l}0.0679 * \\
(0.0471)\end{array}$ & $\begin{array}{l}0.0768 \\
(0.0507)\end{array}$ & $\begin{array}{l}0.0791 \\
(0.0558)\end{array}$ \\
\hline RCD & $\begin{array}{l}-0.28719 \\
(0.4845)\end{array}$ & & & \\
\hline RLS & & $\begin{array}{l}1.2590^{*} \\
(0.6729)\end{array}$ & & \\
\hline RKS & & & $\begin{array}{l}0.00603 \\
(0.1112)\end{array}$ & \\
\hline RMS & & & & $\begin{array}{l}0.0350 \\
(0.5582)\end{array}$ \\
\hline R-squared & 0.1563 & 0.2312 & 0.1472 & 0.1472 \\
\hline F-statistic & 1.977 & $3.208 * *$ & 1.841 & 1.842 \\
\hline $\begin{array}{l}\text { Notes: Standard errors in parentheses } \\
\text { Observations }=36 \\
* * * \text { indicates significance at the } 1 \% \text { level } \\
* * \text { indicates significance at the } 5 \% \text { level } \\
* \text { indicates significance at the } 10 \% \text { level }\end{array}$ & & & & \\
\hline
\end{tabular}

Among the profit measures included in the regressions reported in Table 2, only the average profit rate approaches statistical significance. The weak relationship for average profit and the absence of a relationship for change in profit contrasts to other studies of Kaleckian investment models (especially, Courvisanos, 2007). This is perhaps not surprising given the differences in the data used in estimation. Here, we are using cross-section data for different industries within Australian manufacturing over a limited sample period, 2001-02 to 2004-05. Each industry is affected by the same general business cycle conditions. In contrast, Courvisanos (2007) uses timeseries data from 1984 to 1998, covering two expansions out of significant recessions. 
In that study, there is a larger role for business conditions (as reflected in average profitability and change in profitability) to affect investment rates over the length of the business cycle than with other factors, such as technical change, which alter only slowly.

The regression results in Table 2 also identify the significance of RLS and average operating profit to the four-year (2001-02 to 2004-05) investment block in the specified manufacturing industries, but the model lacks any lagged profits variable as identified in the Kaleckian investment theory. Thus, in the spirit of the cross-section analysis being conducted, a separate regression exercise is introduced. Each industry's four-year average operating profit for the period 1997-98 to 2000-01 (as a ratio of each industry's average IVA) is regressed, with its respective RLS ratio against the same four-year investment block. In effect, the four years of profits prior to this fouryear investment block are a lagged profit variable. This is an alternative way of empirically testing Kalecki's lagged profit variable. The data for this lagged period do not include data for industry 214, Oil and Fat manufacturing. Thus, the number of industry groups reduces to 35 . The results with the lagged profit variable are reported in Table 3.

The results reported in Table 3 show a strong (F-statistic) regression result with a very significant four-year block profit variable. Note that RLS is still mildly significant so that the technical change relationship is still relevant. The variable showing change in operating profit is not included in the block lag test because it lacks significance in the prior test. This variable also has no theoretical meaning within the context of regressing across two block periods, when change in profits only refers to the one (current) investment block already used in Table 2.

Table 3 - Average Investment Rate in Australian Manufacturing 2001/02 to 2004/05 -Regression Results with RLS and Lag Profit Data

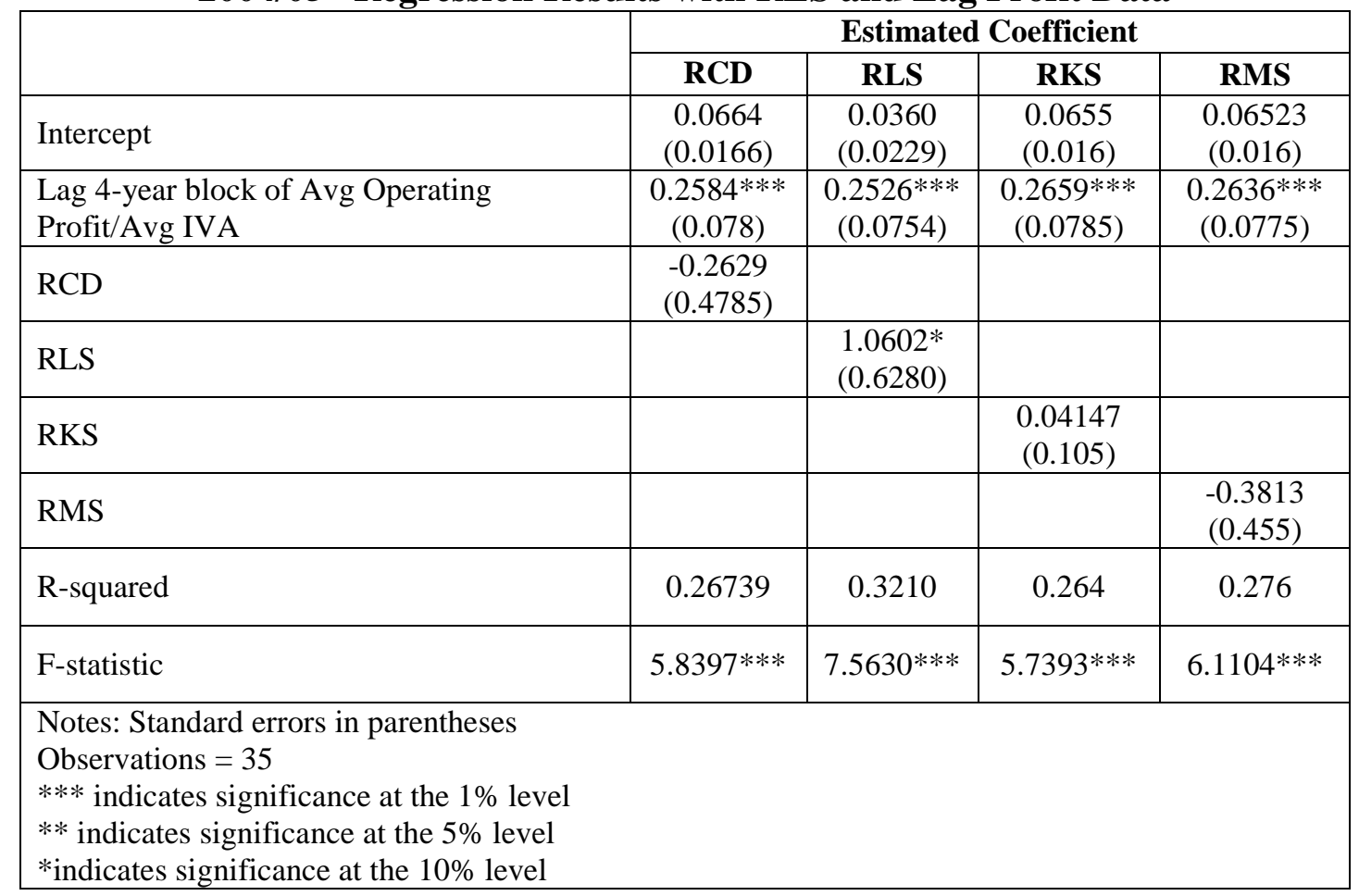


Technical change can impact on the variability of investment as well as on its level. Our estimates give the rate of input saving on average over a 32-year sample period, but it is unlikely that the course of technical change is smooth. Instead, it is expected that there will be periods of rapid advance interspersed with less technological developments. To this extent, industries with more rapid average input saving might also exhibit more uneven induced technological obsolescence and resulting investment. Further, in the context of Kaleckian investment theory, upswings in business conditions may increase susceptibility of investment so that investment might be unstable as profitability rises.

Table 4 presents results from regressions for two measures of the variability of the investment rate, (i) the variance of the investment rate and, (ii) the standard error given by the square root of the variance. The explanatory variables are the rate of labour saving, which is the only statistically significant measure of technical change from Table 2, the average profit rate and change in profit.

The explanatory power of the regressions in Table 4 greatly exceeds those of the regressions in Table 2. However, the only consistently significant coefficient in the regression is the change in profit variable, which is positive and highly significant. This indicates that industries that experience a greater positive change in their profit rate also exhibit greater investment instability. Consistent with Kalecki, the investment instability is related to profit changes. Salter helps to support the Kaleckian investment model by linking the investment rate to each industry's technical change and technological obsolescence, as well as its respective overall profits. 
Table 4 - Variation in Investment Rate in Australian Manufacturing 2001/02 to 2004/05 - Regression Results

\begin{tabular}{|c|c|c|}
\hline Coefficient / Dependent Variable & $\begin{array}{c}\text { Variance of } \\
\text { Investment Rate }\end{array}$ & $\begin{array}{l}\text { Standard Error o } \\
\text { Investment Rate }\end{array}$ \\
\hline Intercept & $\begin{array}{c}-0.0028 \\
(0.0023)\end{array}$ & $\begin{array}{l}-0.0092 \\
(0.0167)\end{array}$ \\
\hline Avg Operating Profit/Avg IVA & $\begin{array}{c}0.0035 \\
(0.0067) \\
\end{array}$ & $\begin{array}{c}0.0411 \\
(0.0500)\end{array}$ \\
\hline Change in Operating Profit/Avg IVA & $\begin{array}{c}0.0169 * * * \\
(0.0033)\end{array}$ & $\begin{array}{c}0.0950 * * * \\
(0.0248)\end{array}$ \\
\hline RLS & $\begin{array}{c}0.0738 \\
(0.0477) \\
\end{array}$ & $\begin{array}{c}0.7185^{* *} \\
(0.3548) \\
\end{array}$ \\
\hline R-squared & 0.4965 & 0.4120 \\
\hline F-statistic & $10.5192^{* * *}$ & $7.473^{* * *}$ \\
\hline \multicolumn{3}{|l|}{ 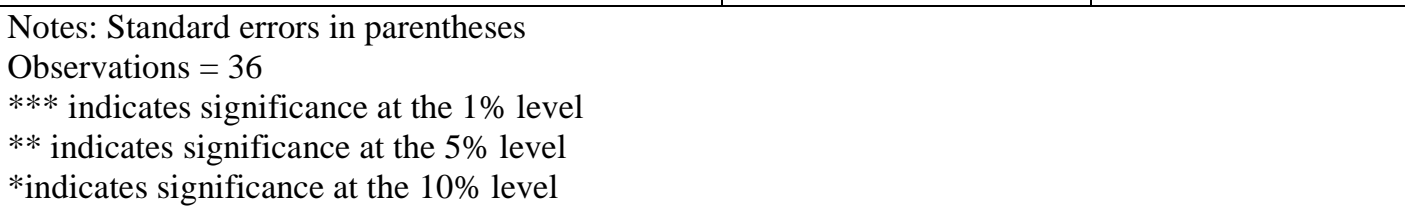 } \\
\hline
\end{tabular}

\section{Conclusions}

This study examines whether technical change and investment are independent or interdependent contributors to technical progress (defined as rising labour productivity). By formalising the Salter approach into the Kaleckian investmentordering model, the rate of labour saving becomes a crucial element in identifying technological obsolescence, and in this way recognising when technical change augments capital accumulation. New capital stock is introduced that results in the older vintage stock being decommissioned as technologically obsolete. In the process, labour is saved and labour productivity rises.

Estimated rates of input saving (labour, capital and materials) obtained for Australian manufacturing sector show that technical change has a significant labour-saving bias. Using the Salter approach, this bias is the dominant element determining the technological obsolescence of old vintage capital equipment, which suggests the need to include the rate of labour-saving technical change as a proxy for technological change into the Kaleckian investment-ordering model. Regression results then indicate that the rate of labour saving combines with lagged profits to provide an explanation of gross investment in Australian manufacturing. Instability in investment spending is further found to depend positively on the strength of labour saving and on changes in profits.

These results show technical change and accumulation are strongly interdependent in Australian manufacturing. The labour-saving bias in technical change encourages investment to replace technologically obsolete equipment and to expand to production capacity. The introduction of the new equipment then raises labour productivity, which can contribute to higher profits, thereby further enhancing the accumulation process in a prototype advanced capitalist economy. 
One central insight of post-Keynesian economics, in which Kalecki played a prominent role, is that investment drives saving because it generates income and additional effective demand. ${ }^{22}$ This macroeconomic feedback from investment to profits is the source of saving in the community. In his A Treatise on Money, Keynes (1931) called it the Widow's Cruse, while Kalecki's Dictum states that "capitalists earn what they spend, and workers spend what they earn" (Sawyer, 1985, p.73). ${ }^{23}$ What this study does is contribute to analysing the form of this investment. Keynes referred to "fruitful investment" in the context of productive expenditure on capital stock that is not speculative investment (Keynes, 1936, p.150). We take this one step further and identify the nature of fruitful investment in terms of the ability to invest and extent of technical progress through innovation that is embodied in the capital accumulation process. Investment that incorporates technological change enables industries to become sustainable into the uncertain future, but with varying states of investment instability.

\footnotetext{
${ }^{22}$ See Harcourt (2006, and in particular pp. 160-4).

${ }^{23}$ Professor Geoffrey Harcourt suggests that Kalecki’s Dictum would be better phrased as “....wageearners spend what they earn while profit-receivers receive what they spend.” (Dalziel and Lavoie, 2003, p. 340 fn.4).
} 


\section{References}

Bloch, Harry (1990), "Price Leadership and the Degree of Monopoly", Journal of Post Keynesian Economics, 12 (3), 439-445.

Bloch, Harry (2009), “Technological Change in Australian Manufacturing”, Australian Economic Review, forthcoming.

Bloch, Harry and Madden, Gary (1995), "Productivity Growth in Australian Manufacturing: A Vintage Capital Model”, International Journal of Manpower, 16, 21-30.

Courvisanos, Jerry (1996), Investment Cycles in Capitalist Economies: A Kaleckian Behavioural Contribution. Cheltenham UK: Edward Elgar.

Courvisanos, Jerry (2005), "Technological Innovation: Galbraith, the Post Keynesians and a Heterodox Future”, Journal of Post Keynesian Economics, 28 (1), 83102.

Courvisanos, Jerry (2007), "The Dynamics of Innovation and Investment, with Application to Australia 1984-1998.” In R. Holt and S. Pressman (eds), Empirical Post Keynesian Economics: Looking at the Real World, Armonk: M. E Sharpe, 141-177.

Davidson, Paul (1994), Post Keynesian Macroeconomic Theory. Cheltenham, UK: Edward Elgar.

Dalziel, Paul and Lavoie, Marc (2003), “Teaching Keynes’s Principle of Effective Demand Using the Aggregate Labor Market Diagram.” Journal of Economic Education, 34 (4), 333-340.

Frankel, Marvin (1955), "Obsolescence and Technological Change in a Maturing Economy.” The American Economic Review, 45, 296-319.

Harcourt, Geoffrey Colin (1972), Some Cambridge Controversies in the Theory of Capital. Cambridge: Cambridge University Press.

Harcourt, Geoffrey Colin (2006), The Structure of Post-Keynesian Economics: The Core Contributions of the Pioneers. Cambridge: Cambridge University Press.

Kalecki, Michal (1968), “Trend and Business Cycle Reconsidered." Economic Journal, 78 (2), 263-76; reprinted with minor changes in Kalecki, Michal (1971), Selected Essays on the Dynamics of the Capitalist Economy, 19331970. Cambridge: Cambridge University Press, 165-183.

Keynes, John Maynard (1931), A Treatise on Money. London: Macmillan.

Keynes, John Maynard (1936), The General Theory of Employment, Interest and Money, London: Macmillan. 
Laramie, Anthony J. and Mair, Douglas (2003), "Obsolescence and the Economic Rate of Depreciation: A Kaleckian Approach.” Merrimack College, North Andover, USA (mimeo).

Laramie, Anthony J., Mair, Douglas, and Miller, Anne G. (2007), “Kaleckian Investment Model: A Critical Realist Perspective.” In R. Holt and S. Pressman (eds), Empirical Post Keynesian Economics: Looking at the Real World. Armonk: M. E Sharpe, 178-199.

Nair, Suresh K. and Hopp, Wallace J. (1992), "Model for Equipment Replacement due to Technological Obsolescence.” European Journal of Operational Research, 63 (2), 207-221.

Perelman, Michael (2006), “The Neglect of Replacement Investment in Keynesian Economics”, Review of Political Economy, 18 (4), 547-559.

Ricardo, David [1821] (1973), The Principles of Political Economy and Taxation. London, J. M. Dent and Sons.

Salter, Wilfred Edward Graham (1966), Productivity and Technical Change, 2d edition. Cambridge: Cambridge University Press.

Sawyer, Malcolm C. (1985), The Economics of Michat Kalecki. London: Macmillan.

Whelan, Karl (2002), "Computers, Obsolescence and Productivity.” The Review of Economics and Statistics, 84 (3), 445-461. 